\title{
The effects of fasting in Ramadan
}

\section{Serum uric acid and lipid concentrations}

\author{
BY K. A. GUMAA,* K. Y. MUSTAFAt, N. A. MAHMOUD \\ AND A. M. A. GADER \\ Departments of Biochemistry and Physiology, Faculty of Medicine, University of \\ Khartoum, Sudan
}

(Received 24 February 1978 - Accepted 6 April 1978)

\begin{abstract}
I. The changes in serum levels of uric acid and lipids during I month of starvation-refeeding were measured in sixteen male volunteers.

2. Uric acid levels increased linearly with the duration of the experiment. The increase was positively correlated with the increase in serum triglycerides but not with cholesterol or phospholipids.

3. Triglycerides increased at a faster rate than uric acid implying that the increase in uric acid was secondary to that of the lipid.

4. It was concluded that the purine and lipid synthetic pathways are linked through a common smallmolecular-weight effector rather than through the sharing of a common enzyme.
\end{abstract}

Throughout the holy lunar month of Ramadan, moslems are expected to abstain from food and drink daily between dawn and sunset. The incidence of renal colic or of angina pectoris increases noticeably during this Islamic month especially when the latter coincides with the hot, dry summer in the Sudan. The question whether these complaints are due to increases of risk factors predisposing to renal calculi and to coronary vascular disease consequent upon the dietary pattern during Ramadan remained to be answered.

When breaking their fast at sunset, Sudanese moslems consume large volumes of sugarsweetened juices to quench thirst, and foods rich in carbohydrates are eaten from sunset till dawn. Nicholls \& Scott (1972) reported that energy restriction leads to a decrease in the plasma level of uric acid and attributed this partly to the relative hydration state associated with weight loss. Increased carbohydrate intake, especially sucrose, is known to increase the triglyceride concentration in serum (Anderson, Grande, Matsumoto \& Keys, 1963; Nestel, Carrol \& Haverstein, I970; Fry, Spector, Connor \& Connor, 1973; Roberts, I973; Sacks, Castelli, Donner \& Kass, 1975).

The present study reports the changes in the serum levels of uric acid and lipids during daily starvation-refeeding over a period of $28 \mathrm{~d}$ in an attempt to test their relationship to the associated complaints of renal colic or angina. Correlation studies were used to test the relation between uric acid and lipid metabolism during periods of maximal dehydration and rehydration throughout the $28 \mathrm{~d}$.

\section{MATERIALS AND METHODS}

The present investigation took place in the Facuty of Medicine, University of Khartoum, Sudan. Sixteen male students aged between 20 and 22 years volunteered for the study, which was to span the one month of Ramadan. All volunteers were healthy as evident from a general medical examination and none was receiving any medication.

Venous blood was collected into clean tubes and allowed to clot at room temperature.

* Present Address: Department of Biochemistry, Faculty of Medicine, Kuwait University, PO Box 5969, Kuwait.

$\dagger$ Piesent Address: Department of Physiology, Faculty of Medicine, Kuwait University, PO Box 5969, Kuwait. 


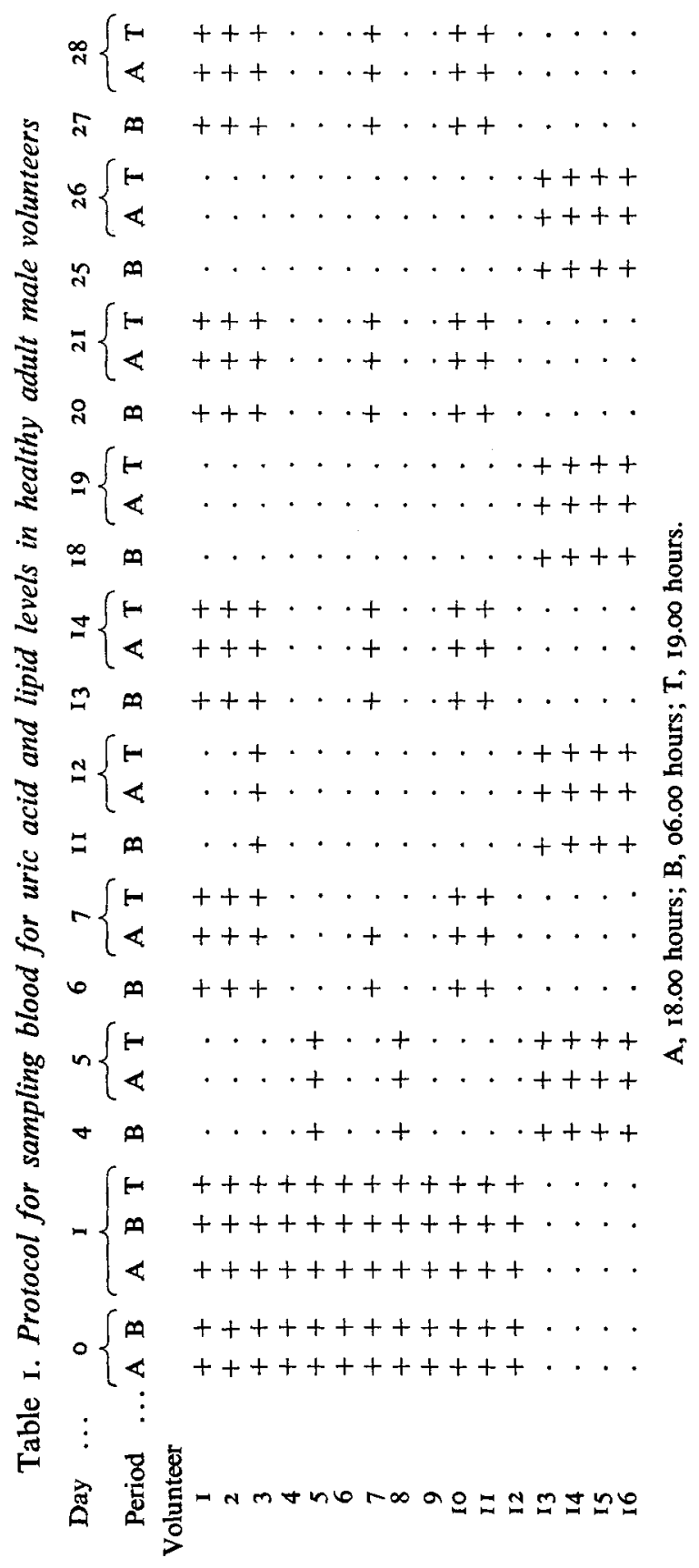


Table 2. Levels of serum uric acid and lipids (mmol/l) during period A (sampled at 18.00 hours) for healthy adult male volunteers during fasting-refeeding in Ramadan $\dagger$

(Mean values with their standard errors; values were obtained by transforming the corresponding mean log. The number of observations for cach measurement is given in Table I).

\begin{tabular}{|c|c|c|c|c|c|c|c|c|c|c|}
\hline \multirow{2}{*}{$\begin{array}{l}\text { Day } \\
\text { no. }\end{array}$} & \multicolumn{2}{|c|}{ Uric acid } & \multicolumn{2}{|c|}{ Triglycerides } & \multicolumn{2}{|c|}{ Cholesterol } & \multicolumn{2}{|c|}{ Phospholipids } & \multicolumn{2}{|c|}{ Total lipids } \\
\hline & Mean & SE & Mean & SE & Mean & $\mathbf{S E}$ & Mean & SE & Mean & SE \\
\hline 0 & 0.255 & 0.014 & 0.856 & 0.098 & $4 \cdot 22$ & 0.097 & 1.55 & 0.059 & $7 \cdot 99$ & 0.396 \\
\hline I & 0.254 & 0.009 & 0.298 & $0.086^{* * *}$ & $4 \% 45$ & 0.087 & $1 \cdot 52$ & 0.121 & $8 \cdot 36$ & 0.255 \\
\hline 5 & 0.268 & 0.003 & $0 \cdot 384$ & $0.034^{* * * *}$ & $3 \cdot 47$ & $0.188^{* * * *}$ & $2 \cdot 35$ & $0.059 * * *$ & $9 \cdot 10$ & 0.440 \\
\hline 7 & 0.238 & 0.019 & 0.496 & $0.053^{* *}$ & $4 \cdot 14$ & 0.334 & $2 \cdot 22$ & $0.150^{* * *}$ & $8 \cdot 62$ & 0.847 \\
\hline 12 & 0.273 & 0.014 & 0.645 & 0.106 & $3 \cdot 37$ & $0.255^{* *}$ & $2 \cdot 49$ & $0.144^{* * *}$ & $8 \cdot 94$ & 0.255 \\
\hline 14 & 0.243 & 0.026 & 0.670 & 0.098 & 391 & $0.073^{*}$ & $1 \cdot 77$ & 0.089 & $9 \cdot 3 I$ & $0.424^{*}$ \\
\hline 19 & 0.309 & $0.02 I^{*}$ & 0.707 & 0.210 & $4 \cdot 56$ & 0.410 & $2 \cdot 34$ & $0.214^{* * *}$ & $9 \cdot 29$ & $0.231 *$ \\
\hline 21 & 0.311 & $0.013^{* *}$ & 0.918 & 0.067 & 3.89 & 0.205 & $1 \cdot 89$ & 0.184 & $9 \cdot 28$ & 0.544 \\
\hline 26 & 0.323 & $0.017^{* *}$ & 0.980 & 0.149 & 492 & $0 \cdot 166^{* * *}$ & $2 \cdot 10$ & $0.039^{* * *}$ & $9 \cdot 44$ & 0.871 \\
\hline 28 & 0.311 & $0.014^{* *}$ & I.09I & 0.263 & $3 \cdot 83$ & $0.12 I^{*}$ & $1 \cdot 88$ & $0.15^{8}$ & $9 \cdot 77$ & 0.910 \\
\hline
\end{tabular}

Mean values statistically different from those for day $0:{ }^{*} P<0.050,{ }^{* *} P<0.010,{ }^{* * *} P<0.005$. $\dagger$ For details, see p. 575 and Table I.

Table 3. Levels of serum uric acid and lipids (mmol/l) during period B (sampled at 06.00 hours) for healthy adult male volunteers during fasting-refeeding in Ramadant

(Mean values with their standard errors; values were obtained by transforming the corresponding mean log. The number of observations for each measurement is given in Table 1 )

\begin{tabular}{|c|c|c|c|c|c|c|c|c|c|c|}
\hline \multirow{2}{*}{$\begin{array}{c}\text { Day } \\
\text { no. }\end{array}$} & \multicolumn{2}{|c|}{ Uric acid } & \multicolumn{2}{|c|}{ Triglycerides } & \multicolumn{2}{|c|}{ Cholesterol } & \multicolumn{2}{|c|}{ Phospholipids } & \multicolumn{2}{|c|}{ Total lipids } \\
\hline & Mean & SE & Mean & SE & Mean & SE & Mean & SE & Mean & SE \\
\hline 0 & 0.255 & 0.014 & 0.856 & 0.098 & $4 \cdot 22$ & 0.097 & I. 55 & 0.059 & 7.99 & 0.396 \\
\hline I & 0.209 & $0.008^{*}$ & 0.372 & $0.066^{* *}$ & $4 \cdot 07$ & 0.109 & 0 & $0.099 * * *$ & $8 \cdot 18$ & 0.344 \\
\hline 4 & 0.238 & 0.010 & 0.446 & $0.065^{* * *}$ & $3 \cdot 83$ & 0.247 & $2 \cdot 58$ & $0.15 I^{* * *}$ & $6 \cdot 86$ & 0.474 \\
\hline 6 & 0.236 & 0.025 & 0.980 & 0.073 & $3 \cdot 26$ & $0.192 * * *$ & $2 \cdot 3$ & $0.242 * * *$ & $8 \cdot 34$ & 0.385 \\
\hline II & 0.232 & 0.010 & $0.78 \mathrm{I}$ & 0.21 & $3 \cdot 94$ & 0.2 & $1 \cdot 9$ & $0.115^{*}$ & 8.07 & 0.359 \\
\hline 13 & 0.228 & 0.027 & $I \cdot I 66$ & 0.158 & $3 \cdot 60$ & $0.106^{* * *}$ & $I \cdot 5$ & 0.118 & 10.08 & \\
\hline 18 & 0.296 & $0.009^{*}$ & I 128 & $0.063^{*}$ & $4 \cdot 38$ & 0.392 & 2 & $0.120^{* * *}$ & 8.82 & $I \cdot 420$ \\
\hline 20 & 0.257 & 0.015 & $\mathbf{I} \cdot \mathbf{I}$ & 0.282 & 4.0 & & & 0.429 & 10.86 & $0.968 *$ \\
\hline 25 & 0.292 & 0.021 & $1 \cdot 190$ & 0.236 & 4.01 & & $1 \cdot 57$ & 0.262 & & 0.768 \\
\hline & 0.263 & 0.015 & $I \cdot 4 I 4$ & 0.290 & 3.83 & $0.118^{*}$ & $1 \cdot 69$ & 0.149 & $8 \cdot 38$ & 0.720 \\
\hline
\end{tabular}

Mean values statistically different from those for day 0 : * $P<0.050,{ }^{*} P<0.010$, *** $P<0.005$.

† For details, see p. 575 and Table 1.

When the clot retracted, serum was transferred to plastic tubes and stored at $-18^{\circ}$ until subsequent analysis. Each student served as his own control by comparing his Ramadan with his pre-Ramadan serum levels of uric acid and lipids. Sampling was performed at 06.00 hours (period B), I8.00 hours, just before breaking the fast (period A), and at $19 . \mathrm{n}$ hours, after breaking the fast (period $\mathrm{T}$ ) according to the scheme shown in Table $\mathrm{I}$.

The serum uric acid levels were determined by the method of Caraway (1955). Tot:l cholesterol was determined by the method of Levine \& Zak (1964). Phospholipids were determined by the method of Bartlett (1959). The triglycerides were determined after extraction and transesterification (Royer \& Ko, 1969) by the Hantzch condensation reaction using the method of Soloni (1971). Total lipids were determined colorimetrically by the sulphophosphovanillic reaction (Zollner \& Kirsch, 1962). Serum 3-hydroxybutyrate was measured by the method of Williamson, Mellanby \& Krebs (1962). 
Table 4. Levels of serum uric acid and lipids ( $\mathrm{mmol} / \mathrm{l}$ ) during period T (sampled at 19.00 hours) for healthy adult male volunteers during fasting-refeeding in Ramadan $\dagger$

(Mean values with their standard errors; values were obtained by transforming the corresponding mean $\log$. The number of observations for each measurement is given in Table $\mathrm{I}$ )

\begin{tabular}{|c|c|c|c|c|c|c|c|c|c|c|}
\hline \multirow{2}{*}{$\begin{array}{l}\text { Day } \\
\text { no. }\end{array}$} & \multicolumn{2}{|c|}{ Uric acid } & \multicolumn{2}{|c|}{ Triglycerides } & \multicolumn{2}{|c|}{ Cholesterol } & \multicolumn{2}{|c|}{ Phospholipids } & \multicolumn{2}{|c|}{ Total lipids } \\
\hline & Mean & $\mathbf{S E}$ & Mean & SE & Mean & SE & Mean & SE & Mean & SE \\
\hline 0 & 0.255 & 0.014 & 0.856 & 0.098 & $4 \cdot 22$ & 0.097 & $t \cdot 55$ & 0.059 & 7.99 & 0.396 \\
\hline I & 0.279 & 0.010 & 0.285 & $0.077^{* * *}$ & $4 \cdot 43$ & 0.113 & $I \cdot 45$ & 0.100 & $8 \cdot 75$ & 0.320 \\
\hline 5 & 0.290 & $0.009^{*}$ & 0.645 & 0.084 & $2 \cdot 82$ & $0.239^{* * *}$ & $2 \cdot 26$ & $0.3^{84}$ & $7 \cdot 88$ & 0.710 \\
\hline 7 & 0.294 & 0.024 & 0.818 & 0.153 & $4 \cdot 12$ & 0.296 & $2 \cdot 18$ & 0.311 & 8.01 & 0.440 \\
\hline 12 & 0.315 & $0.010^{* * *}$ & 0.868 & 0.238 & $3 \cdot 34$ & $0.152^{* * *}$ & $2 \cdot 32$ & $0.342^{*}$ & $9 \cdot 29$ & $0.272^{*}$ \\
\hline 14 & 0.292 & 0.036 & 1.054 & 0.137 & $4 \cdot 12$ & 0.210 & 1.89 & $0.13 I^{*}$ & 7.96 & 0.448 \\
\hline 19 & 0.330 & $0.023^{*}$ & 0.942 & 0.235 & 4.53 & 0.452 & $2 \cdot 84$ & $0.301 * * *$ & $8 \cdot 73$ & $I \cdot 064$ \\
\hline 21 & 0.323 & $0.018 * *$ & $I \cdot 190$ & $0.026^{* * *}$ & 3.65 & $0.094^{* * *}$ & 1.46 & 0.237 & $7 \cdot 88$ & 0.176 \\
\hline 26 & $0.34 I$ & $0.017^{* * *}$ & 0.980 & 0.145 & $4 \cdot 30$ & 0.304 & 1.98 & $0.163^{*}$ & I I $\cdot 25$ & $1 \cdot 933$ \\
\hline 28 & 0.332 & 0.020 & 1.091 & 0.208 & $4 \cdot 12$ & 0.150 & $2 \cdot 34$ & 0.277 & $7 \cdot 55$ & 0.289 \\
\hline
\end{tabular}

Mean values statistically different from those for day $0:{ }^{*} P<0.050,{ }^{* *} P<0.010,{ }^{* * *} P<0.005$. $\dagger$ For details, see p. 575 and Table I.

Table 5. Correlations between the mean logs of serum uric acid and lipid levels and the duration of fasting-refeeding for healthy adult male volunteers during Ramadan $\dagger$

$\begin{array}{cccccc}\text { Period } & \text { Uric acid } & \text { Triglycerides } & \text { Cholesterol } & \text { Phospholipids } & \text { Total lipids } \\ \text { A } & 0.8177^{* *} & 0.9725^{* *} & 0.2497 & 0.0741 & 0.8826^{* *} \\ \text { B } & 0.7923^{* *} & 0.8449^{* *} & 0.3172 & 0.1680 & 0.5238 \\ \text { C } & 0.9185^{* *} & 0.7700^{*} & 0.2865 & 0.1278 & 0.1978\end{array}$

A, 18.00 hours; B, 06.00 hours; $T$, I9.00 hours.

$* P<0.050, * * P<0.010$.

$\dagger$ For details, see p. 576 and Table I.

\section{Statistical analysis}

All results were analysed for significant difference from the values obtained on day 0 of the experiment by Student's $t$ test. Values of $P>0.05$ were considered not significant.

\section{RESULTS}

The small size of the groups studied precluded the investigation of the type of distribution of serum lipids and of uric acid. Berkowitz (1966); Gunther, Knapp \& Siller (1968) and Mielants, Veys \& De Weerdt (1973a) reported that the distribution of serum uric acid and lipids is of the log-normal type.

The serum levels of uric acid, triglycerides, cholesterol, phospholipids and of total lipids are shown in Tables 2-4 for the sampling periods A, B and T respectively; the tabulated means were derived by transforming their corresponding log values (Snedecor \& Cuchran, 1974).

\section{Uric acid}

There was no change in serum uric acid level in period A of the first 2 weeks of fastingrefeeding (Table 2). During the subsequent 2 weeks the uric acid level increased significantly $(P<0.05-<0.01)$ by $21-27 \%$ compared with the previous value for period A. On the other hand, during period $\mathrm{B}$ the serum uric acid level initially decreased significantly $(P<0.05)$ by $18 \%$ and subsequently increased gradually towards the prefasting level 
Table 6. Correlations between serum uric acid and lipid levels for healthy adult male volunteers during Ramadan $\dagger$

Period ...

Uric acid $v$. triglycerides

Uric acid $v$. total lipids

Total lipids $v$, triglycerides

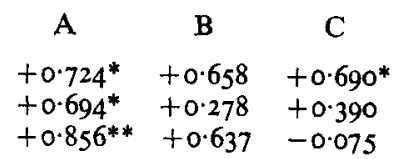

A, I8.00 hours; B, 06.00 hours; T, 19.00 hours.

$* P<0.050,{ }^{*} P<0.010$.

$\dagger$ For details, see p. 577 and Table $I$.

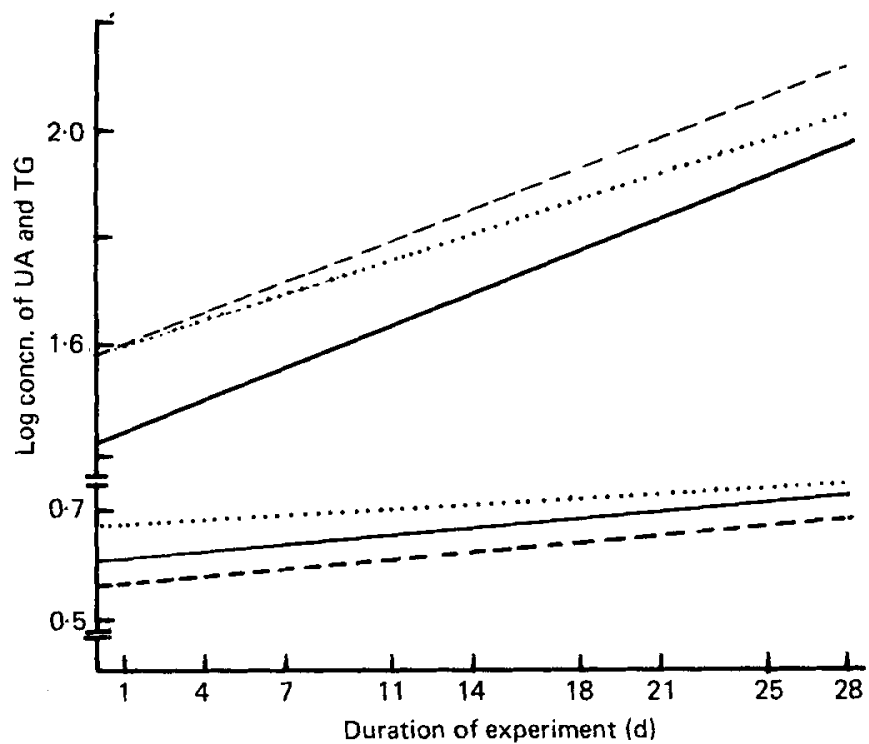

Fig. I. Regression lines for log concentrations of serum uric acid (UA) and triglycerides (TG) $v$. duration of experiment (d) for healthy adult male volunteers during fasting-refeeding in Ramadan (for details, see p. 577 and Table I). _- Period A, I 8.00 hours; -- , period B, o6.00 hours; $\cdots$, period T, 19.00 hours. Correlation coefficients: TG: A $0.0195 ; \mathrm{B}, 0.0185$, T 0.0155; UA: A $0.0044, \mathrm{~B} 0.0043$, T $0.003 \mathrm{I}$.

(Table 3). In contrast, there was a gradual significant increase to a maximum of $34 \%$ during period $\mathrm{T}$ (Table 4 ). The increases in the serum levels of uric acid correlate positively with the duration of the experiment (Table 5), and with the triglycerides (Table 6).

\section{Triglycerides}

In all three periods, after an initially significant decrease in the level of serum triglycerides, there was a gradual increase to levels higher than the mean prefasting level. However, the increase was not statistically significant except for period B of the $27^{\text {th }}$ day. The lack of statistical significance can be attributed to the large range of levels encountered and the small size of the groups. The increase in the level of serum triglycerides correlates positively with the duration of the experiment (Fig. I) and with the total lipids during period A (Table 6). 


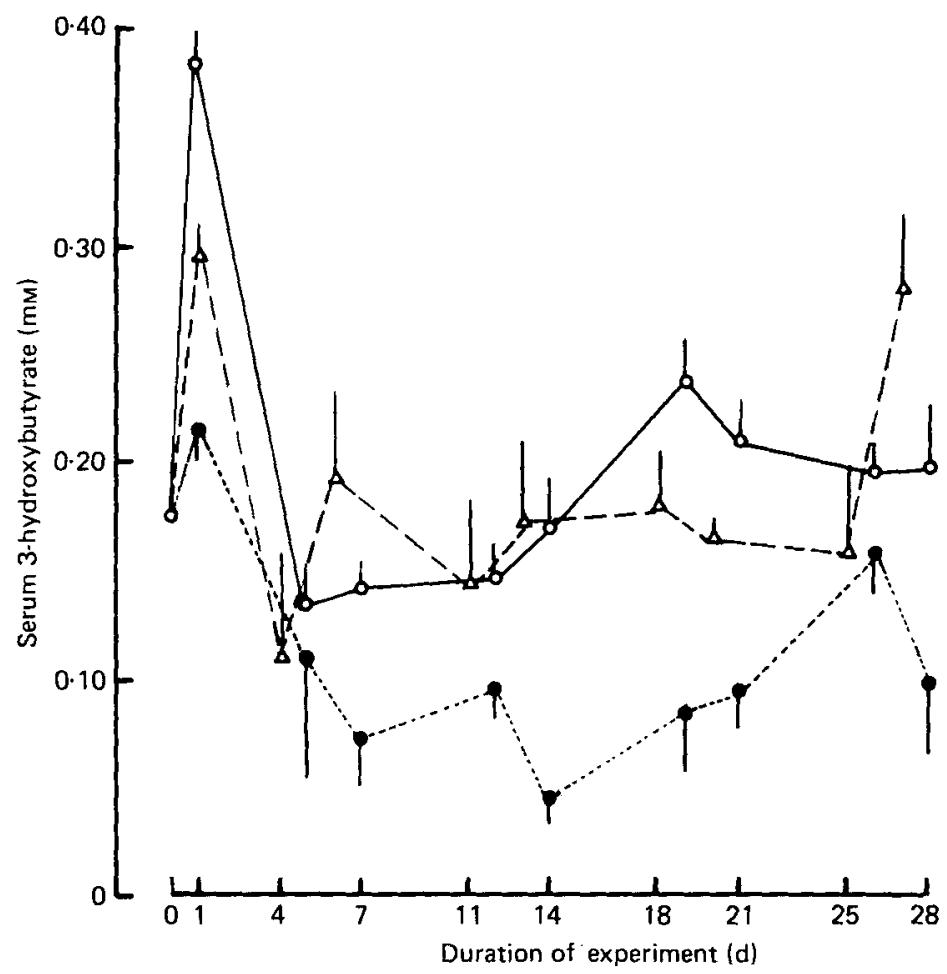

Fig. 2. The changes in the serum concentration of 3-hydroxybutyrate ( $\mathrm{mm}$ ) during fasting-refeeding in Ramadan for healthy adult male volunteers (for details, see p. 578 and Table I). ——, period A, 18.00 hours; - - , period B, 06.00 hours; $\cdots$, period T, 19.00 hours. Vertical bars represent the standard errors of the means.

\section{Cholesterol}

During period $A$ there was an average decrease of $4 \%$ in the level of serum cholesterol. In periods $\mathrm{B}$ and $\mathrm{T}$ the decrease was 8 and $7 \%$ respectively. No particular pattern for the decrease was noted in any of the three periods.

\section{Phospholipids}

The serum level of phospholipids increased significantly by $30-34 \%$ during the three periods, but like cholesterol there was no particular pattern for the increase. It was noted that the level of phospholipids was approximately $50 \%$ of the level found in the controls by Mielants et al. (1973a), but was in keeping with values for normal subjects studied in this laboratory.

\section{Total lipids}

The level of serum total lipids showed a tendency to increase throughout the duration of the experiment. The largest increase was for period A, $14 \%$, while in periods $\mathrm{B}$ and $\mathrm{T}$ values increased by 10 and $7 \%$ respectively. The increase during period A was statistically significant $(P<0.05)$.

\section{3-Hydroxybutyrate}

The level of serum 3-hydroxybutyrate increased during the first day of the experiment and subsequently returned to prefasting level for periods A and B (Fig. 2). However, in period $T$, after an initial increase, the level of serum 3-hydroxybutyrate decreased below the prefasting level. 


\section{DISCUSSION}

Weight loss through restriction of energy intake was reported to be associated with a significant decrease in serum uric acid levels which was not accompanied by an increased excretion of urate in the urine (Nicholls \& Scott, 1972). These authors proposed that their findings could be partly due to the relative hydration associated with weight loss and to a decreased rate of purine synthesis when energy intake is restricted. In support of those findings, Semple, Henderson \& Boyle (1974) demonstrated that fasting decreased the rate of purine synthesis de novo by the possible feedback inhibition of the enzyme formyl glycinamide ribonucleotide amidotransferase $(E C 6.3 .5 \cdot 3)$ by nucleotides derived from the catabolism of RNA (Wyngaarden \& Ashton, 1959; Munro, 1968) consequent on fasting.

The present study revealed that intermittent fasting and refeeding is associated with an increase in the serum level of uric acid which correlates positively with the duration of the experiment for all three periods, A, B and T (Table 5). In contrast with the low-carbohydrate diet used by Nicholls \& Scott (1972) to decrease body-weight, the diet consumed by the subjects in the present study was rich in carbohydrates, mainly sucrose, as a sweetener for the massive amounts of juices consumed at sunset to break the fast. Since the highest levels of serum uric acid were observed in period $\mathrm{T}$, the increase in serum uric acid level cannot be attributed to dehydration. This increase in the level of serum uric acid may have either been due to increased de novo synthesis of purines concomittant on refeeding, or from increased breakdown of RNA in tissues during fasting (Munro, Naismith \& Wikramanayake, 1953). The increasing concentration of serum uric acid coupled to the oliguria from dehydration (K. Y. Mustafa, N. A. Mahmoud, K. A. Gumaa, \& A. M. A. Gader unpublished results) may predispose to the crystallization of the acid within the urinary tract to produce dysuria and the attacks of renal colic often encountered during this month of fasting. Scott, McCallum \& Holloway (1964) showed that starvation ketosis decreases the rate of uric acid excretion. In the present study, except for a small increase in serum 3-hydroxybutyrate level in the first day of fasting (Fig. 2), there was no ketosis to explain the observed increase in the level of serum uric acid.

The kinetics of serum triglycerides revealed that after the initial significant decrease in its concentration the increase was linearly correlated with the duration of the experiment (Table 5). This would be expected in view of the increased carbohydrate intake, mainly in the form of sucrose, throughout the duration of the experiment (Anderson et al. 1963; Nestel et al. 1970).

The increase in the serum concentration of triglycerides correlated significantly $(P<$ $0.001)$ with the increase in serum uric acid concentration $(r+0.9 \mathrm{I},+0.89$ and +0.90 for periods $\mathrm{A}, \mathrm{B}$ and $\mathrm{T}$ respectively). Although this correlation is in agreement with the findings of many workers, the mechanism responsible for this relationship is still not clear. Mielants, Veys \& De Weerdt (1973b) postulated that lipid and purine metabolism are genetically linked through a hypothetical enzyme which is defective in gout. In the present study the slopes of the regression lines for uric acid and triglycerides $v$. duration of experiment (Fig. I) differed widely for all three periods of the experiment. The greater slopes for the triglyceride correlations with the duration of the experiment relative to those for uric acid implied that the change in purine metabolism may be consequent upon the change in lipid metabolism. The link between the two pathways is more likely to be a small-molecular-weight effector, the redox state or the energy charge than a common enzyme. In this context, it is interesting to note that Jakovcic \& Sorensen (1967) postulated that in Type I glycogen-storage disease, the deficiency of the enzyme glucose-6-phosphatase $(E C$ 3.1.3.9) leads to an intracellular accumulation of glucose-6-phosphate which acts as a substrate for de novo purine synthesis via the pentose phosphate pathway, and the reducing equivalents generated, i.e. $\mathrm{NADPH}_{2}$, 
promote lipogenesis. The observation that there is a simultaneous decrease of both the triglycerides and uric acid in the serum of gouty patients treated with lipid-lowering drugs (Berkowitz, 1965), and a decrease in serum triglycerides in gouty patients treated with uric acid-lowering drugs (Bluestone, Lewis \& Mervart, I97I) can be attributed to feedback control of one pathway of synthesis on the other.

Gout was reported to be associated with hypercholesterolaemia (Becker, I960), but Gibson \& Grahame (1974) could not confirm this association. In the present study with normal subjects, no correlation was observed between the increasing serum uric acid level and cholesterol, in agreement with observations on gouty patients (Mielants et al. 1973b). Similarly there was no correlation between levels of phospholipids and uric acid in the present study. On the other hand, uric acid levels were positively correlated with levels of total lipids, the correlation being of border-line significance. This may be in part due to the correlations already observed between the levels of serum total lipids and one of its components, the triglycerides, which as noted previously were closely correlated with levels of serum uric acid (Table 6).

The evidence linking hyperuricaemia with ischaemic heart disease (Dawber, Moore \& Mann, 1957; Hall, I965) has been attributed to the association of hyperuricaemia with hypertriglyceridaemia, the latter being associated with coronary vascular disease (Charlson \& Bottiger, 1972). The increase in serum triglycerides during fasting-refeeding with a highcarbohydrate diet is not necessarily a risk factor predisposing to coronary heart disease since it was recorded that a slow adaptation to the high-carbohydrate diet occurs and leads to low serum triglycerides levels (Antonis \& Bersohn, 1960, 1961).

It is concluded that prolonged fasting and refeeding leads to increases of both serum uric acid and triglycerides. The association between hypertriglyceridaemia and hyperuricaemia is unlikely to be through a common enzyme (Mielants et al. 1973b), but rather through feedback interaction between the pathways of metabolism mediated through smallmolecular-weight effectors or similar modulators.

The authors are grateful to Mrs R. Bishara, Mr M. El Hag and Mr S. Hassan for skilled technical assistance.

\section{REFERENCES}

Anderson, J. T., Grande, F., Matsumoto, Y. \& Keys, A. (1963). J. Nutr. 79, 349.

Antonis, A. \& Bersohn, I. (1960), Lancet i, 998.

Antonis, A. \& Bersohn, I. (1961). Lancet i, 3.

Bartlett, G. R. (1959). J. biol. Chem. 234, 466.

Becker, J. H. (1960). Wis. med. J. 59, 735.

Berkowitz, D. (1965). Metabolism 14, 966.

Berkowitz, D. (1966). J. Am. med. Ass. 197, 77.

Bluestone, R., Lewis, B. \& Mervart, I. (1971). Ann. rheum. Dis. 3o, I34.

Caraway, W. T. (1955). Am. J. clin. Path. 25, 840.

Charlson, L. A. \& Bottiger, L. E. (1972). Lancet i, 865.

Dawber, T. R., Moore, F. E. \& Mann, G. V. (1957). J. publ. Hith 47, no. 4, part 2, p. 4.

Fry, M. M., Spector, A. A., Connor, S. L. \& Connor, W. E. (1973) Am. J. clin. Nutr. 26, 798.

Gibson, T. \& Grahame, R. (1974). Ann. rheum. Dis. 33, 298.

Gunther, R., Knapp, E. \& Siller, K. (1968). Wien. Klin. Wschr. 80, 473.

Hall, A. P. (1965). Arthritis Rheum. 8, 846.

Jakovcic, S. \& Sorensen, L. B. (1967). Arthritis Rheum. 1o, 129.

Levine, J. B. \& Zak, B. (1964). Clinica chim. Acta 10, 38I.

Mielants, H., Veys, E. M. \& De Weerdt, A. (1973a). Ann. rheum. Dis. 32, 501.

Mielants, H., Veys, E. M. \& De Weerdt, A. (1973 b). Ann. rheum. Dis. 32, 506.

Munro, H. N. (1968). Fedn Proc. Fedn Am. Socs exp. Biol. 27, 1231.

Munro, H. N., Naismith, D. J. \& Wikramanayake, T. W. (I953). Biochem. J. 53, 198.

Nestel, P. J., Carrol, K. F. \& Haverstein N. (1970). Metab. clin. Expt 19, I. 
Nicholls, A. \& Scott, J. T. (1972). Lancet ii, 1223.

Roberts, A. M. (1973). Lancet i, I 201.

Royer, M. E. \& Ko, H. (1969). Analyt. Biochem 29, 405.

Sacks, F. M., Castelli, W. P., Donner, A. \& Kass, E. H. (1975). N. Engl. J. Med. 292, I 48.

Scott, J. T., McCallum, F. M. \& Holloway, V. P. (1964). Clin. Sci. 27, 209.

Semple, P. F., Henderson, A. R. \& Boyle, J. A. (1974). Clin. Sci. mol. Med 46, 37.

Snedecor, G. W. \& Cochran, W. G. (1974). Statistical Methods. 6th ed., p. 329. Ames, Iowa: Iowa State University Press.

Soloni, F. G. (I97I). Clin. Chem. 17, 529.

Williamson, D. H., Mellanby, J. \& Krebs, H. A. (1962). Biochem. J. 82, 90.

Wyngaarden, J. B. \& Ashton, D. M. (1959). J biol. Chem. 234, 1492.

Zollner, N. \& Kirsch, K. (1962). Z. ges. exp. Med. 135, 545. 